\title{
Investigation of postural edema in the lower extremities of traffic control workers
}

\author{
Investigação de edema postural de membros inferiores em agentes de trânsito
}

Ana Paula Nunes Pereira Brito', Étria Rodrigues', Denise Loureiro Vianna', Susi Mary de Souza Fernandes

\begin{abstract}
Objective: Determine the prevalence of postural edema and investigate whether working posture - sitting down or standing up - affect its frequency. Methods: Sixteen traffic control agents were assessed by water displacement volumetry and the results were analyzed in two groups, depending on working posture. Those who worked standing up for more than 4 hours were allocated to the SU group and those who worked sitting down for more than 4 hours were allocated to the SD group. Each worker was assessed before and after their working shift for three consecutive days. Data were analyzed using ANOVA and the test of equality of two proportions. The significance level was set at $p \leq 0.05$. The assessment showed that members of both groups had postural edema of the lower extremities ( $p$ $\leq$ 0.001). Results: When the frequency of postural edema was compared across groups, a trend was observed for greater edema formation in the SU group than in the SD group, although without statistically significant difference. Conclusion: It was concluded that traffic control agents suffer postural edema after 4 hours working in either of the postures investigated although with a predominance of edema formation among those who work standing up.

Keywords: edema; lower extremities; health occupational.

Resumo

Objetivo: Avaliar a ocorrência de edema postural (EP) e verificar se há diferença na sua formação entre as duas posturas de trabalho adotadas - em pé e sentada. Métodos: Foram avaliados 16 trabalhadores agentes de trânsito por meio da volumetria por deslocamento de água, divididos em dois grupos de acordo com a posição de trabalho adotada. No Grupo em Pé (GP), foram alocados aqueles que trabalhavam em pé e, no Grupo Sentado (GS), aqueles que adotavam a posição sentada, ambos por mais de quatro horas consecutivas. Os dados foram coletados antes e após a jornada de trabalho por três dias consecutivos e tratados com os testes estatísticos ANOVA e lgualdade de duas proporções. O nível de significância adotado foi $p \leq 0,05$. A avaliação revelou presença de edema postural de membros inferiores nas duas condições avaliadas ( $p \leq 0,001)$. Resultados: Na análise da diferença na formação de EP entre os grupos, observou-se tendência a maior formação no GP em comparação ao GS, contudo sem diferença estatisticamente significante. Conclusão: Concluiu-se que existiu EP em agentes de trânsito após quatro horas de trabalho nas duas condições avaliadas com predomínio na formação de edema na postura em pé.
\end{abstract}

Palavras-chave: edema; membros inferiores; saúde ocupacional.

\footnotetext{
${ }^{1}$ Universidade Presbiteriana Mackenzie - UPM, Barueri, SP, Brazil. 


\section{INTRODUCTION}

The workplace can be a significant cause of deaths, diseases and incapacity for a considerable number of workers ${ }^{1,2}$ related to risks inherent to working environment ${ }^{3}$. Correct occupational health surveillance includes conducting workplace risk assessments before implementing specific strategies for promotion, protection and recovery of workers' health ${ }^{1}$. Knowledge of the risks makes preventive guidance possible $\mathrm{e}^{4,5}$.

In occupational settings, postural edema (PE) is a significant clinical condition that members of the working population can suffer if they remain standing or seated for periods longer than 4 hours. The condition causes discomfort, premature tiredness and a feeling of heaviness and may progress to vascular disease $e^{6,7}$.

Postural edema has insidious onset and its defining characteristic is accumulation of liquid in the lower extremities (LE). Its occurrence is related to the physiological mechanism resulting from increased pressure exerted on venous capillaries in the LE that are unable to overcome the force of gravity ${ }^{8}$. While $\mathrm{PE}$ can also affect healthy individuals, it is considered a primary indicator of functional decompensation of the venous system, which can lead to the emergence of chronic venous insufficiency (CVI) of the LE. Chronic venous insufficiency is a disease of the venous system that can cause complications with negative impact on people's lives ${ }^{7,9}$. In Brazil, CVI is the 14th most common cause of worker absenteeism ${ }^{6}$.

As part of daily work, traffic control agents are also exposed to other risk factors, such as poorly paved and maintained roads and sidewalks and the weather with its extremes of temperature and wind $^{10,11}$. In conjunction with these factors, PE affects both individuals and society because of the reduction in quality of life that it causes and because it undoubtedly reduces workers' productivity ${ }^{6}$.

The objective of this study is to investigate the occurrence of PE among traffic control agents who work in one of two postures - sitting or standing - in order to provide a basis for the development of preventative measures tailored to this population.

\section{MATERIAL AND METHODS}

\section{Ethical considerations}

The research protocol (number FT0060812) was submitted to and approved by the local Research Ethics Committee before any of the data collection stages were initiated.
This quantitative study was conducted by the Universidade Presbiteriana Mackenzie. A total of 40 males who work as traffic control agents for the municipal authority of Barueri, São Paulo, were invited to take part. Just 16 of these people met the inclusion criteria defined for the study, which were: male sex; aged over 18; working as a traffic control agent for at least 1 year; working for more than 4 hours consecutively; free from diabetes mellitus and systemic arterial hypertension; not on diuretic or hormonal drugs; and provision of voluntary consent by means of signature of a free and informed consent form. Subjects with serious vascular disease or diseases of the skin or nails of the foot or if they did not comply with the protocol were excluded from study.

There are no conflicts of interests related to the study and no financial support was received.

\section{Allocation of subjects}

The subjects enrolled on the study were allocated to one of two groups depending on their posture while working. Seven people who spent more than 4 hours standing up while conducting traffic patrols on foot were allocated to the SU group. Nine people who worked sitting down for more than 4 hours, conducting traffic patrols on motorcycles or performing administrative tasks, were assigned to the SD group.

\section{Assessment measures}

Subjects underwent volumetric assessment by water displacement at two points in time per day, the first before starting a work shift and the second immediately after coming off the same shift. Each subject was assessed for three consecutive days.

A heat resistant glass vessel with the following measurements was used: $50 \mathrm{~cm}$ high $\times 40 \mathrm{~cm}$ long $\times$ $15 \mathrm{~cm}$ wide. The vessel had a single aperture through which water could exit via a tube located on one side at a height of $40 \mathrm{~cm}$ (Figure 1 - Vessel used for water displacement volumetric assessments). This vessel was filled up to the exit aperture with water heated to $30{ }^{\circ} \mathrm{C}$. The exit was left open and excess water that flowed through it was drawn off through a cannula. The water was considered leveled when no more water flowed out of the vessel.

The study participants presented at the prearranged place and time and were requested to remove their footwear and wash their feet before immersing their right lower extremity into the vessel, slowly in order to avoid creating excessive turbulence 
(Figure 2 - Volumetric assessment of postural edema).

As the extremity was immersed, the water displaced was collected into a container with a scale with $100 \mathrm{ml}$ intervals. The remaining liquid above the last full $100 \mathrm{ml}$ was removed and placed in a 100 $\mathrm{ml}$ measuring cylinder and the volume was read off in milliliters. The total volume of water displaced was recorded.

After their shifts, participants returned for a repeat assessment.

\section{Statistical analysis}

Statistical analysis was conducted using the ANOVA test for parametric data and the test of equality of two proportions for nonparametric data. The significance level adopted was $\mathrm{p}<0.05$ and

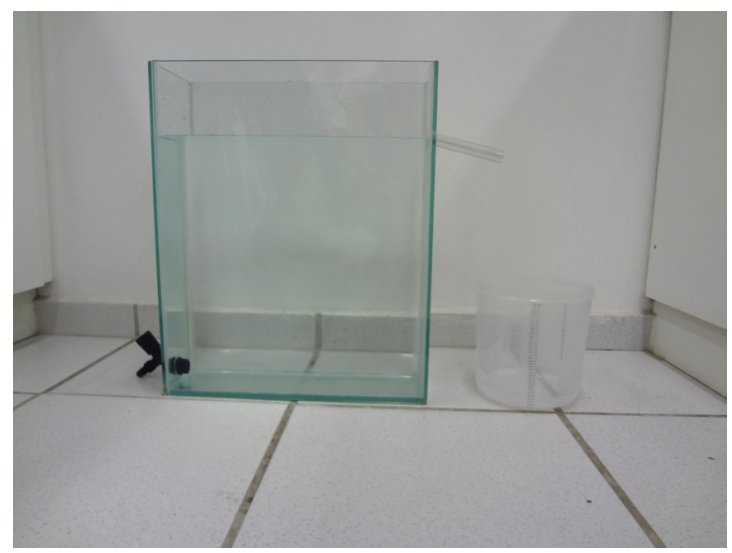

Figure 1. Vessel employed for water displacement volumetric assessments.

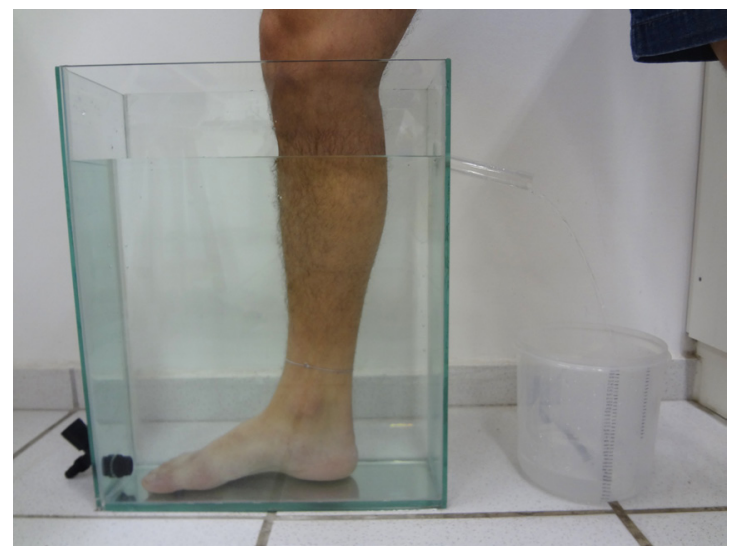

Figure 2. Volumetric assessment of postural edema. the mean confidence interval gave $95 \%$ statistical confidence.

\section{RESULTS}

The results of this study relate to 16 participants allocated to one of two groups: $\mathrm{SU}(\mathrm{n}=7)$ or $\mathrm{SD}$ $(n=9)$. Their demographic characteristics are given in Table 1.

As shown in Table 2, each pair of results for one person's water displacement assessment on a single day was treated as a separate data point, meaning that the SU group $(n=7)$ were assessed 21 times over 3 consecutive days, while the SD group $(n=9)$, were assessed 27 times. There was a statistically significant difference $(\mathrm{p}<0.001)$ between the number of subjects with and without edema in both groups.

In order to evaluate the difference in distribution of edema between the two groups, a variable denominated Greatest Difference was calculated by subtracting the smallest measurement before starting a shift from the largest measurement taken

Table 1. Demographic data.

\begin{tabular}{lcccc}
\hline Variable & $\mathrm{n}$ & $\begin{array}{c}\text { Age } \\
\text { (years) }\end{array}$ & $\begin{array}{c}\text { Weight } \\
(\mathrm{kg})\end{array}$ & $\begin{array}{c}\text { Height } \\
(\mathrm{cm})\end{array}$ \\
\hline Standing Up Group & 7 & $33 \pm 4.96$ & $85 \pm 8.34$ & $1.76 \pm 6.18$ \\
Sitting Down Group & 9 & $31 \pm 9$ & $76 \pm 10$ & $1.72 \pm 4.32$ \\
\hline
\end{tabular}

Table 2. Distribution of postural edema across groups.

\begin{tabular}{|c|c|c|c|c|c|}
\hline \multirow[b]{2}{*}{ Edema } & \multicolumn{2}{|c|}{ Standing up } & \multicolumn{2}{|c|}{ Sitting down } & \multirow[b]{2}{*}{$P$} \\
\hline & $\begin{array}{c}\text { Number of } \\
\text { assessments }\end{array}$ & $\%$ & $\begin{array}{c}\text { Number of } \\
\text { assessments }\end{array}$ & $\%$ & \\
\hline Absent & 2 & $9.5 \%$ & 5 & $18.5 \%$ & 0.381 \\
\hline Present & 19 & $90.5 \%$ & 22 & $81.5 \%$ & \\
\hline$P$ & \multicolumn{2}{|c|}{$<0.001$} & \multicolumn{2}{|c|}{$<0.001$} & \\
\hline
\end{tabular}

Table 3. Absolute difference in edema between groups.

\begin{tabular}{lcc}
\hline \multirow{2}{*}{ Absolute } & \multicolumn{2}{c}{ Greatest Difference } \\
\cline { 2 - 3 } & Standing up & Sitting down \\
\hline Mean & 239.9 & 205.7 \\
Median & 237 & 200 \\
Standard deviation & 64.4 & 91.4 \\
N & 7 & 9 \\
P & & 0.416 \\
\hline
\end{tabular}




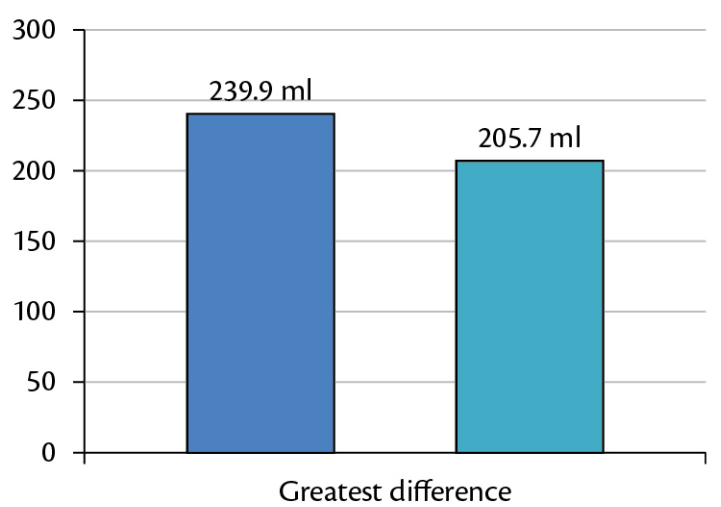

$\square$ Standing up $\quad \square$ Sitting down

Figure 3. Greatest difference.

after finishing a shift, irrespective of which day each measurement was taken. The results for this variable can be seen in Table 3 .

As can be observed in Figure 3, the Greatest Difference was larger in the SU group than the Greatest Difference in the SD group, although without statistical significance $(p=0.416)$, suggesting that $\mathrm{PE}$ is more frequent in the $\mathrm{SU}$ group.

\section{DISCUSSION}

The results of this study revealed PE in traffic control agents who worked in both postures investigated. These findings are in line with previous studies that have demonstrated PE secondary to prolonged periods in a given working position, in a variety of working populations.

Postural edema is a physiological phenomenon caused by an imbalance in the equilibrium between the forces described by Starling's law, in which hydrostatic pressure, which is naturally elevated, is increased beyond the colloid osmotic pressure, causing fluid to migrate from the intracellular compartment to the interstitial compartment ${ }^{12,13}$.

However, this can be further aggravated by remaining in the same position for prolonged periods, since venous hemodynamics are altered during working activities, whether the worker remains sitting, remains standing still or is walking around ${ }^{8}$. Studies have identified postural edema as a predictive sign of CVI, due to reflux or obstructions of venous return $^{9,13}$. Therefore, PE combined with remaining in fixed positions for long times while working should be considered as an aggravating physiological factor in circulatory complications.

In this study a trend was observed for postural edema to be more frequent in the PE group than in the SU group. These findings agree with the literature which shows that remaining standing for a prolonged time and constant ambulation are factors that condition a person to musculoskeletal problems, problems with the joints and vascular conditions because the lumbar spine and the lower extremities become overloaded ${ }^{10}$. This in turn has many unfavorable consequences for workers' health, such as fatigue, pain, discomfort, muscle tension and build up of blood in the legs ${ }^{13}$.

Working in a standing position can only be justified if heavy loads must be handled; for activities that demand large amplitude movements; constant changes of workstation; the application of downward force; and/or continuous displacement ${ }^{14}$. The last of these items describes the principle activity involved in the work of the traffic control agents in the SU group who conduct traffic patrols on foot on the streets, spending long periods standing upright ${ }^{15,16}$.

Postural edema was also found in members of the SD group. It should be pointed out that the majority of participants in the SD group works patrolling the streets on motorcycles. While they undoubtedly spend the majority of their work shifts in a static and unfavorable position as they ride, they do not suffer overload on the buttocks or compression of the thighs and popliteal surface as do those who work sitting in chairs ${ }^{17}$. This explains the lower frequency of PE when compared to the group who work standing up.

Another relevant feature of posture that may help to explain the higher prevalence of edema in the SU group than in the SD group is a comparison between standing and seating positions. Sitting down demands lower energy expenditure and therefore takes less effort ${ }^{1}$. It also allows for trunk and LE movements that can help improve blood flow by compression venous collectors as the muscle pump works properly ${ }^{12}$.

Nevertheless, the fact that edema was detected must not be ignored. Remaining in a seated position for prolonged periods exposes people to increased discomfort. If hip flexion passes $120^{\circ}$, venous circulation is restricted by localised compression of vessels which in turn makes edema of LE more likely to emerge ${ }^{17,18}$.

A study of postural disorders of the spine among military policemen who patrol on motorcycles found that most of the motorcyclists studied adopted a posture with an exaggerated degree of forward trunk flexion, in order to reach the handlebars ${ }^{19}$. This finding might explain the presence of postural edema in the SD group in the present study. 
The emergence of PE among the traffic control agents may also be partly explicable by other factors, not being exclusively the result of the posture adopted while working. A study of the functional characteristics of the boots worn by military police found that inappropriate footwear has a significant negative impact on regulation and control of movement of the ankle joint, in addition to being uncomfortable and causing problems with the circulation ${ }^{20}$.

During the assessments conducted for this study, it was observed that all of the traffic control agents were wearing this type of footwear. Inappropriate footwear compounds the static forces demanded of the muscles, whether standing or sitting, and rapidly leads to muscle fatigue and strangulation of both the venous and lymphatic capillaries, compromising blood flow and lymphatic flow, respectively. This in turn can involve a risk of thrombi forming in the deep and superficial venous systems ${ }^{21}$.

It is known that active movement of the LE plays a fundamental role in the dynamics of venous return. It causes muscular compression of the sural pump, which is located in the calf, reducing venous stasis by increasing venous flow volumes and providing an average of $1,134.59 \mathrm{ml}$ every time the pump is activated by plantar flexion movements and dorsiflexion of the ankle ${ }^{22,23}$.

Chronic venous insufficiency is triggered by several factors and the risk conferred by remaining standing or sitting for prolonged periods. Suffering edema as a result is just one of those factors and several other factors also have an influence on the emergence of what is the principal indicator of venous diseases.

The duration of working shift can have an effect. There is greater fluid buildup during the morning and during the afternoon, although venous hemodynamics change throughout the day, as valve cusp separation produces reflux ${ }^{7,8}$.

During their working day, traffic control agents are exposed to several other risk factors, including poorly paved and maintained streets and sidewalks, exposure to varying degrees of natural illumination and urban noise, in addition to the weather with its extremes of temperature and wind ${ }^{12,24}$.

Constant exposure to heat can have a direct influence on peripheral liquid accumulation and can help to cause PE, because high temperatures provoke vasodilation of capillaries and increase their permeability, since, in contrast to plasma volume, which is controlled by arterial baroreceptors and volume receptors in low pressure territories, edema is aggravated by an imbalance between hydrostatic pressure and colloid osmotic pressure, to the extent that they have a direct impact on whether there is more or less liquid in the $\mathrm{LE}^{8,10,12}$.

Central venous insufficiency of the LE is one of the most common conditions that affect the population. In Brazil, the government has begun to consider its importance over recent years, since there is a consensus of medical opinions that work can have a direct effect on aggravating this condition ${ }^{21}$.

Scientific evidence shows that prevention and treatment of PE of the LE of workers who spend long periods either sitting or standing, and also of the symptoms associated with it, improves quality of life and reduces employee absenteeism ${ }^{6,21}$.

Graduated elastic compression stockings (GECS) offer both a method for prevention and treatment to contain edema in the legs, by exerting the ideal pressure on veins in the region, thereby aiding venous return to the heart ${ }^{6-8}$.

The GECS grade should be chosen on the basis of the function for which they have been prescribed. Preventative or prophylactic support stockings should provide compression of less than $15 \mathrm{mmHg}$, whereas stockings prescribed for treatment provide compression levels greater than $15 \mathrm{mmHg}$. The latter are, therefore, the preferred option for treating $\mathrm{CVI}^{25}$. Another technique that is based on the same principles as compression stockings is application of functional bandages, although they provide less pressure which means that the body is allowed a greater variation in tissue pressures and free movement is less restricted ${ }^{25}$.

Metabolic leg exercises can also relieve the symptoms of tiredness and feelings of weight and fatigue in the LE that are caused by edema. Performing physical exercise with the LE is of fundamental importance to optimize venous physiology because it can increase blood flow velocity by $200 \%$ by provoking repetitive contraction of the sural pump which increases return ${ }^{6,11}$.

Adopting a position in which the legs are raised to an angle $\geq 180^{\circ}$ when lying down is also importante since this can both equalize hydrostatic and colloid osmotic pressures in a few minutes and eliminate the effect of the force of gravity that is present when standing or sitting ${ }^{6,8,11,26}$.

While the present study has certain methodological limitations related to the number of participants and their representativeness, the results are in line with the literature showing that traffic control agents suffer from PE, which if ignored will compromise their ability to work and as a result their quality of life. 
Considering that PE is a predictive sign of the development of venous disease, periodic assessments and early intervention to avoid its emergence could reduce socioeconomic problems such as employee absenteeism and even invalidity retirements, in addition to enhancing day-to-day and leisure activities $^{6,8}$ for this working population.

In view of the morbidity detected, it is recommended that programs and guidelines be implemented for health promotion, prevention and recovery in traffic control agents in order to modify the current deficiency of interventions specifically designed to protect the occupational health of this working population.

\section{CONCLUSIONS}

The results revealed that traffic control agents who worked in both postures analyzed had postural edema.

When the groups were compared, the results revealed a trend for edema to be more likely in the group that worked standing up than in the group that worked sitting down.

\section{REFERENCES}

1. Deliberato PCP. Fisioterapia Preventiva: fundamentos e aplicações. São Paulo: Manole; 2002.

2. Brasil. Ministério da Saúde. Secretaria de Políticas de Saúde. Departamento de Atenção Básica. Saúde do Trabalhador. Brasília: Ministério da Saúde; 2001.

3. Santos $A C B C$. Sistema de gestão de saúde e segurança do trabalho em um centro de terapia intensiva de João Pessoa: aspectos relacionados com o estresse ocupacional [dissertação]. João Pessoa: Universidade Federal da Paraíba; 2004.

4. Beltrán CA, Moreno MP, Rodriguez MGA, López TMT, Estrada JGS. Relación de variables sociodemográficas y laborales com manifestaciones clínicas em trabajadores agentes de tránsito, México. Rev Costarric Salud Pública. 2008;17(33):32-9.

5. Fernandes $S$, Rodrigues $E$, Vianna DL. Efeito da hidroterapia no edema de membros inferiores. Rev Mackenzie Educ Fis Esporte. 2011;10(1):89-97.

6. Silva ZP, Barreto IF Jr, Sant'ana MC. Saúde do Trabalhador no âmbito municipal. São Paulo em Perspec. 2003;17(1):47-57. http:// dx.doi.org/10.1590/S0102-88392003000100006

7. França LHG, Tavares V. Insuficiência venosa crônica: uma atualização. J Vasc Bras. 2003;2(4):318-28.

8. Belczak CEQ, Godoy JMP, Ramos RN, Oliveira MA, Belczak SQ, Caffaro RA. Influência do turno laboral na formação de edema dos membros inferiores em indivíduos normais. J Vasc Bras. 2008;7(3):225-30. http://dx.doi.org/10.1590/ S1677-54492008000300007

9. Belczak CEQ, Godoy JMP, Seidel AC, Silva JÁ, Cavalheri JRG, Belczak SQ. Influência da atividade diária na volumetria dos membros inferiores medida por perimetria e pela pletismografia de água. J Vasc Bras. 2004;3(4):304-10.

10. Gonçalves RMA, Lancman S, Jardim TA, Sznelwar LI, Trudel L. O trabalho dos agentes de trânsito do município de São Paulo: uma análise ergonômica. Rev Ter Ocup USP. 2005;16(2):82-9. http:// dx.doi.org/10.11606/issn.2238-6149.v16i2p82-89

11. Kuriyama GS, Moreira JC, Silva CRS. Exposição ocupacional ao dióxido de nitrogênio $\left(\mathrm{NO}_{2}\right)$ em policiais de trânsito na cidade do Rio de Janeiro. Cad Saúde Pública. 1997;13(4);677-83. Pmid:10886908 http://dx.doi.org/10.1590/S0102-311X1997000400010

12. Coelho EB. Mecanismos de formação de edemas. Medicina. 2004;37:189-98

13. Berenguer FA, Silva DAL, Carvalho CC. Influência da posição ortostática na ocorrência de sintomas e sinais clínicos de venopatias de membros inferiores em trabalhadores de uma gráfica na cidade de Recife-PE. Rev Bras Saúde Ocup. 2010;35(122):153-61.

14. Brasil. Ministério do Trabalho e do Emprego. Manual de aplicação da Norma Regulamentadora no 17. 2. ed. Brasília: TEM, SIT; 2002.

15. Barueri. Prefeitura Municipal. Edital Concurso Público - PMB 02/2011. [citado 2012 mar. 20]. www.institutosoler.com.br.

16. Sampaio RFV, Carvalho-Freitas MN, Kemp VH. Estressores ocupacionais e qualidade de vida no trabalho de agentes de trânsito. Pesquisa e Práticas Psicossociais. 2012;7(1):34-43.

17. Garbin AJl, Garbin CAS, Diniz DG. Normas e diretrizes ergonômicas em odontologia: o caminho para a adoção de uma postura de trabalho saudável. Rev Odontol Univ Cid Sao Paulo. 2009;21(2):155-61.

18. Zapater AR, Silveira DM, Vitta A, Padovani CR, Silva JCP. Postura sentada: a eficácia de um programa de educação para escolares. Ciênc Saúde Coltetiva. 2004;9(1):191-9. http://dx.doi.org/10.1590/ S1413-81232004000100019

19. Cavalcanti DPB. Avaliação postural dos desvios da coluna vertebral dos componentes da ROTAM da polícia militar da Paraíba [dissertação]. Campina Grande: Universidade Estadual da Paraíba; 2011.

20. Martins ACV, Melo SIL. Estudo das características funcionais e de uso do coturno utilizado pelo policial militar e sua influência do desempenho na atividade de ronda. Rev Bras Cine Des Hum. 2005;7(1)50-8.

21. Bertoldi CML, Proença RPC. Doença venosa e sua relação com as condições de trabalho no setor de produção de refeições. Rev Nutr Campinas. 2008;21(4):447-54. http://dx.doi.org/10.1590/ S1415-52732008000400009

22. Campos CCC, Albuquerque PC, Braga IJS. Avaliação do volume de fluxo venoso da bomba sural por ultra-sonografia Doppler durante cinesioterapia ativa e passiva: um estudo piloto. J Vasc Bras. 2008;7(4):322-5. http://dx.doi.org/10.1590/ S1677-54492008000400007

23. Belczak CEQ, Cavalheri G Jr, Godoy JMP, Caffaro RA, Belczak SQ Relação entre mobilidade da articulação talocrural e a úlcera venosa. J Vasc Bras. 2007;6(2):149-55. http://dx.doi.org/10.1590/ S1677-54492007000200009

24. Belczak CEQ, Godoy JMP, Ramos RN, Oliveira MA, Belczak SQ, Caffaro RA. Comparison of reduction of edema after rest and after muscle exercises in treatment of chronic venous insufficiency. Int Arch Med. 2009;2:18. PMid:19602249 PMCid:PMC2717934. http://dx.doi.org/10.1186/1755-7682-2-18

25. Sociedade Brasileira de Angiologia e Cirurgia Vascular. Terapia de compressão de membros inferiores. São Paulo: Associação Médica Brasileira, Conselho Federal de Medicina; 2011. Projeto Diretrizes. Participantes: Figueiredo MAM, Castro AA, Simões R.

26. Partsch H, Winiger J, Lun B. Compression stocking reduce occupational leg swelling. Dermatol Surg. 2004;30(5):737-43. PMid:15099316. http://dx.doi. org/10.1111/j.1524-4725.2004.30204.x 
Correspondence Ana Paula Nunes Pereira Brito

Rua Luanda, 8, Vila Ema CEP 06321-170 - Carapicuíba (SP), Brazil Fone: +55 (11) 96590-3020 E-mail: paula.npb@hotmail.com

\section{Author's information} APNPB Physical Therapy student, Universidade Presbiteriana Mackenzie (UPM).

ERMSc in Morphological Sciences from Universidade Cidade de São Paulo (UNICID) and professor at the School of Physical Therapy, Universidade Presbiteriana Mackenzie. DLV PhD in Sciences from the School of Medicine, Universidade de São Paulo (FMUSP), and professor at the School of Physical Therapy, Universidade Presbiteriana Mackenzie.

SMSFMSc in Rehabilitation Sciences from the School of Medicine, Universidade de São Paulo (FMUSP), and professor at the School of Physical Therapy, Universidade Presbiteriana Mackenzie.

Author's contributions Conception and design: SMSF Analysis and interpretation: SMSF, APNPB

Data collection: APNPB Writing the article: SMSF, APNPB

Critical revision of the article: ER Final approval of the article*: APNPB, ER, DLV, SMSF

Statistical analysis: DLV Overall responsibility: SMSF Obtained funding: None.

*All authors should have read and approved of the final version of the article submitted to J Vasc Bras. 